\title{
Er sosial angst noe å bry seg om?
}

\author{
Jevnlig påstås det i mediene at vanlig sosial angst sykeliggjøres som diagnosen sosial fobi \\ ledsaget av salgsfremstøt fra farmasøytisk industri. Dette står i kontrast til toneangivende \\ oversiktsartikler om sosial fobi i The Lancet og New England Journal of Medicine. Er sosial \\ angst kommersielt eller seriøs psykiatri? Det vil vi belyse nærmere i denne kronikken.
}

\section{Alv A. Dahl}

a.a.dahl@imbv.uio.no

Kreftklinikken

Radiumhospitalet

Oslo universitetssykehus, Rikshospitalet

\section{Ida M. Wiborg}

Klinikk for psykisk helse

Oslo universitetssykehus, Aker

Siden det ikke finnes norske undersøkelser av forekomsten av ulike sosiale angstfenomener, henviser vi til data fra den store nasjonale befolkningsundersøkelsen i USA (NCS-R) (1) (tab 1). Her beskrives livstidsforekomsten av 14 ulike sosial angst-situasjoner. Situasjonene kan greit deles i prestasjonsangst og angst for omgang med andre mennesker. $24 \%$ av befolkningen bekrefter å ha hatt en eller flere av dem i løpet av livet. Siden amerikanere kulturelt sett synes mer vant til sosial eksponering og markedsføring av seg selv enn vi nordmenn, er kanskje prevalenstallene høyere i Norge?

\section{Sosial angst er vanlig}

Hva er innholdet i sosial angst? Jo, man er redd for å dumme seg ut, bli til latter, få jernteppe, virke nervøs, få kritikk eller bli avvist. Kroppslige reaksjoner som rødming, skjelving eller svetting hører også med. Siden kanskje en av fire av oss har hatt slik sosial angst, kan noen og hver kjenne seg igjen. Det å ha sosial angst i sosiale situasjoner gir ikke uten videre grunnlag for verken diagnose eller behandling. Dersom farmasøytisk industri hevder at alle individer med sosial angst bør tilbys behandling med nye antidepressiver, er det selvsagt

Tabell 1 Livstidsprevalens av ulike sosiale angstsituasjoner og prevalens av sosiale angstsituasjoner blant personer som har livstids sosial fobi i den amerikanske befolkningsundersøkelsen. Utdrag fra tabell etter Ruscio et al (2). 2007 @ Cambridge journals, publisert av Cambridge University Press. Gjengitt med tillatelse

\begin{tabular}{|lcc|}
\hline Angst i følgende situasjoner: & $\begin{array}{c}\text { Prevalens } \\
\text { i befolkningen }(\%) \\
(\mathrm{N}=9282)^{1}\end{array}$ & $\begin{array}{c}\text { Prevalens } \\
\text { ved sosial fobi (\%) } \\
(\mathrm{N}=1 \text { 143) }\end{array}$ \\
\hline Møte nye mennesker & 16,8 & 80,5 \\
\hline Snakke til autoritetspersoner & 14,7 & 72,3 \\
\hline Snakke på møter eller i grupper & 19,5 & 85,3 \\
\hline Gå i selskap & 13,4 & 67,6 \\
\hline Snakke/opptre offentlig & 21,2 & 88,7 \\
\hline Viktig eksamen/intervju & 14,0 & 67,5 \\
\hline Arbeide mens noen ser på & 11,8 & 59,4 \\
\hline Komme sist inn i et rom & 11,9 & 61,1 \\
\hline Snakke til fremmede & 13,1 & 66,7 \\
\hline Uttrykke uenighet & 12,4 & 60,2 \\
\hline Skrive/spise/drikke mens noen ser på & 8,1 & 43,9 \\
\hline Bruke offentlige toalett & 5,7 & 28,1 \\
\hline Gå på stevnemøte (date) & 11,5 & 60,6 \\
\hline Andre typer prestasjonsangst & 15,7 & 76,0 \\
\hline Angst i minst én av disse situasjonene & 24,1 & 100,0 \\
\hline IInklusive de med sosial fobi & & \\
\hline
\end{tabular}

grovt uansvarlig. Sosial angst er så vidt vi vet ikke godkjent som indikasjon for noe medikament i noe land.

Sosial angst har dessuten en tilpasningsfunksjon fordi den kan bidra til at folk finner sin rette plass i den sosiale rangorden, ikke truer autoriteter eller på andre måter virker utfordrende eller ypper til kiv eller konkurranse, atferd som kan lede til mobbing eller sosial utstøtelse.

\section{Forventningsangst og unnvikelsesatferd}

Angst i ulike sosiale situasjoner er altså vanlig. Den har regelmessig to ledsagende symptomer, som ikke nevnes i NCS-R (1). Det ene er forventningsangst, eller for å si det dagligdags: det å grue seg. Dette er «angst for angsten», der man i fantasien ser for seg kommende sosiale situasjon og hvordan angsten gjør at man mislykkes totalt i sin fremtreden. Mange leger vil ha kjent forventningsangsten på kroppen foran eksamener eller ved å gjøre prosedyrer eller inngrep for første gang mens noen ser på. Ofte er forventningsangsten verre enn situasjonsangsten, siden den gjerne fører til søvnproblemer, anspenthet og konsentrasjonsvansker, mens den sosiale situasjonen uunngåelig rykker nærmere dag for dag. Forventningsangst illustreres godt i Fatso (2), en hjerteskjærende skildring av en ung manns lengsel etter kvinnen og hans frykt for avvisning fra henne. Teksten er et lettfattelig eksempel på den lammende effekten av «the need-fear dilemma».

Det andre symptomet er unnvikelsesatferd: det å la være å stille opp i angstsituasjonen og gi en mer eller mindre god bortforklaring. Ved å unnvike slipper man unna angsten, men løsningen kan ha en høy pris. Folk reagerer negativt på dem som alltid sier nei til personalfesten, nekter å spise i kantina eller aldri ytrer seg på arbeidsmøtene. Vi kan vise overbærenhet når en far ikke våger å tale i sin datters bryllup og liknende, siden det er enkelthendelser. Verre er det med mønsteret til dem som gjerne vil ha en kjæreste, men aldri våger å legge opp til et stevnemøte av frykt for avvisning. 


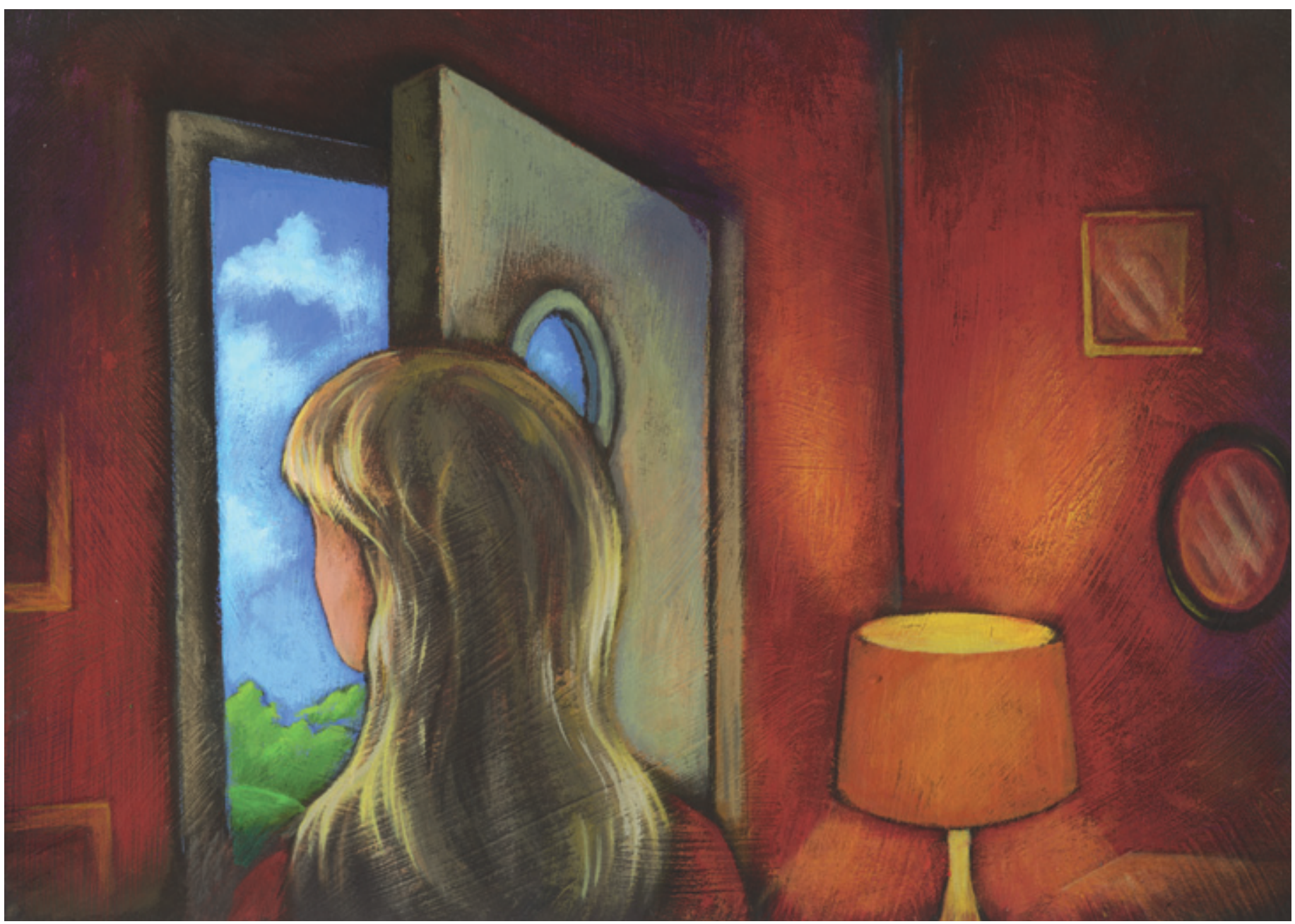

Illustrasjon Stein Løken

Eller for dem der nettpraten går bra, mens det første fysiske møtet blir en katastrofe av rødming, stamming, klamme hender, pinlig taushet og manglende blikkontakt. Det er også verdt å merke seg at svært mye av undervisningen i Norge i dag er gruppebasert med krav om aktiv deltakelse, noe sannsynligvis nærmere $20 \%$ av befolkningen har markert angst for (1).

\section{Sosial angst med «någo attåt»}

Sosial angst av betydning omfatter altså også forventningsangst og unnvikelsesatferd. Triaden av symptomer blir bare til diagnosen sosial fobi i det amerikanske psykiatriske klassifikasjonssystemet (DSM-IV) (3) dersom ett av de tre elementene leder til enten subjektiv lidelse eller funksjonssvikt.

Med subjektiv lidelse menes at individet lider under den plage og de begrensninger som symptomene fører med seg. Et eksempel er det å ha et sterkt ønske om å utdanne seg til politibetjent uten å kunne søke opptak fordi utdanningsplanen for politiskolen baserer seg på gruppearbeid. Eller det å måtte si nei til neste karrieresteg fordi man da må lede møter fremfor bare å være deltaker. Funksjonssvikt betyr at vanlige sosiale rutiner, yrkes- eller utdan- ningsmessig fungering eller sosiale aktiviteter eller funksjoner er alvorlig begrenset.

Vårt offisielle diagnosesystem (ICD-10) krever ikke funksjonssvikt, men bare unnvikelsesatferd for diagnosen sosial fobi. Dette er uheldig fordi mange flere dermed kan få diagnosen på et snevrere grunnlag. All forskning på sosial fobi er gjort i DSMsystemet (4). Det betyr at de forskningsbaserte funnene om sosial fobi er basert på kombinasjonen av den sosiale angsttriaden sammen med subjektiv plage eller funksjonssvikt.

\section{Funksjonssvikt}

Individer med sosial fobi har gjerne flere typer uønskede begrensninger sammenliknet med dem uten diagnosen, slik som lavt utdanningsnivå, sivilstatus som enslig, arbeidsløshet, lavere inntekt, dårligere mental og fysisk helse (inklusive mer alkohol- og stoffmisbruk) (5). Kringlen og medarbeidere fant at individer med sosial fobi hadde dårligere livskvalitet, mindre kontakt med venner og dårligere selvrealisering enn dem uten denne lidelsen (6). Fra Helseundersøkelsen i Oslo beskrev Falk Dahl \& Dahl nylig at individer med sosial fobi var klart mer sosialt isolert og hadde uheldig livsstil med alkoholproblemer og lite mosjon sammenliknet med kontrollpersoner (7). Både sosial isolasjon og uheldig livsstil medfører for øvrig betydelig sykdomsrisiko videre i livet.

\section{Sykelig sjenanse}

«En av siklingekongene het Sigvald, og hans datter het Sigrid. Det var mange som beilet til henne, men hun var så blyg at hun ennå aldri hadde løftet øynene opp til noen mann. Da hennes far sa at hun før eller senere måtte gifte seg og gi ætten sønner og døtre, svarte Sigrid at hun ville gifte seg med den mannen som kunne dra hennes øyne til seg, men han måtte ikke bruke vold.» (8). Sitatet fra Yngre Edda viser at både sykelig sjenanse og de negative konsekvensene av unnvikelsesatferden var velkjent allerede for lang tid tilbake.

Vi sier at en person virker sjenert dersom han/hun ikke sier noe sammen med andre, føler seg ubekvem i sosiale situasjoner, ikke vil komme i fokus for oppmerksomheten eller har store problemer med å møte noen for første gang. I sin vanlige form oppfattes dette som kledelig i norsk kultur: Man skal ikke stå frem eller gjøre for mye ut av seg, jevnfør janteloven. I mange miljøer er det 
å måtte nødes fortsatt en dyd, nærmest som en reaksjonsdannelse mot grådighet. Imidlertid kan disse væremåtene bli så uttalte at de leder til subjektiv plage eller eventuelt funksjonssvikt, slik sitatet om Sigrid viser.

Hemmet atferd (skyhet) i tidlig barndom er en væremåte som disponerer for alvorlig sjenanse og eventuelt sosial fobi senere i livet (9). Blant voksne er det vanskelig å skille sosial fobi med angst for flere situasjoner fra unnvikende personlighetsforstyrrelse, der angsten for avvising er et dominerende trekk i personligheten (10).

\section{Hvordan stille diagnosen?}

For allmennlegen er det viktig å komme på sporet av sosial angst. Pasienter som gir dårlig blikkontakt, rødmer merkbart, har klamme hender eller som stammer eller stotrer i konsultasjonen, bør vurderes nærmere. Det er også vist at tre enkle spørsmål kan være til stor nytte for å identifisere sosial fobi $(4,7,11)$ : «Gjør frykt for å bli forlegen at du unngår å gjøre ting eller snakke til folk?» «Unngår du aktiviteter der du kommer i sentrum for oppmerksomheten?» og «Er det å bli flau eller virke dum blant tingene du er mest redd for?» Positive svar på ett eller flere av disse spørsmålene om unnvikelse og angst bør følges opp med spørsmål om funksjonssvikt.

\section{Behandlingsalternativene}

Er det påvist sosial fobi med ønske om hjelp hos pasienten, er behandlingen enten eksponeringsterapi, kognitiv atferdsterapi eller nye antidepressiver med godkjent indikasjon sosial fobi. Alle disse behandlingene har vist god effekt $(4,12)$, og de kan eventuelt kombineres. Allmennlegen må tilråde behandling ut fra pasientens ønsker og egen kompetanse. Ut fra vår erfaring vil spesialisthelsetjenesten neppe ta imot henvisninger dersom ikke minst én av disse behandlingene er prøvd i allmennpraksis.

\section{Konklusjon}

Sosial angst må tas på alvor dersom pasienten er sterkt subjektivt plaget eller har klar funksjonssvikt, altså sosial fobi. Sosial fobi er hyppig, med en livstidsprevalens på $7 \%$ i befolkningen $(1,6)$. Legen må være aktivt utspørrende overfor pasienten. Diagnosen sosial fobi er enkel å stille og behandlingen gir vanligvis gode resultater.

Oppgitte interessekonflikter: Ingen

\section{Litteratur}

1. Ruscio AM, Brown TA, Chiu WT et al. Social fears and social phobia in the USA: results from the National Comorbidity Survey Replication. Psychol Med 2008; 35: 15-28.

2. Ramslie L. Fatso. Oslo: Oktober forlag, 2003.
3. American Psychiatric Association. Diagnostiske kriterier fra DSM-IV. Oslo: Pilgrim Press, 1997.

4. Stein MB, Stein DJ. Social anxiety disorder. Lancet 2008; 371: 1115-25

5. Kessler RC. The impairments caused by social phobia in the general population: implications for intervention. Acta Psychiatr Scand 2003; 108 (suppl 417): 19-27.

6. Cramer V, Torgersen S, Kringlen E. Quality of life and anxiety disorders: a population study. J Nerv Ment Dis 2005; 193: 196-202.

7. Falk Dahl CA, Dahl AA. Lifestyle and social network in individuals with high level of social phobia/anxiety symptoms: a community-based study. Soc Psychiatry Psychiatr Epidemiol 2009: DOI 10.1007/s00127-009-0069-6

8. Brøgger NC. Nordens demring. Oslo: Ernst G. Mortensens forlag, 1949: 356-7.

9. Fox NA, Henderson HA, Marshall PJ et al. Behavioral inhibition: linking biology and behavior within a developmental framework. Annu Rev Psychol 2005; 56: 235-62

10. Reichborn-Kjennerud T, Czajkowski N, Torgersen $S$ et al. The relation between avoidant personality disorder and social phobia: a population-based twin study. Am J Psychiatry 2007; 164: 1722-8.

11. Connor KM, Kobak KA, Churchill E et al. MINISPIN: a brief screening assessment for generalized social anxiety disorder. Depress Anxiety 2001 14: $137-40$

12. Schneier FR. Social anxiety disorder. N Engl J Med 2006; 355: 1029-36.

Manuskriptet ble mottatt 19.6. 2009 og godkjent 15. 10. 2009. Medisinsk redaktør Siri Lunde. 